\title{
Supporting Self-efficacy and Learner Autonomy in Relation to Academic Success in EFL Classrooms (A Case Study)
}

\author{
Filiz Yalcin Tilfarlioglu \\ Department of English Language Teaching, Faculty of Education, Gaziantep University, Turkey \\ Email: fyalcin@gantep.edu.tr \\ Fatma Seyma Ciftci \\ Adiyaman University, Turkey \\ Email: sciftci@adiyaman.edu.tr
}

\begin{abstract}
This research was conducted for revealing the missing point of the discussions related to foreign language teaching and learning in Turkey. This study intended to investigate the relationship between selfefficacy and learner autonomy, self-efficacy and academic success, learner autonomy and academic success, and these two concepts and academic success. Also, it was aimed to explore the effect of self-efficacy on academic success, the effect of learner autonomy on academic success and the effect of self-efficacy and learner autonomy on academic success. The study was applied to 250 preparatory level students at Gaziantep, Zirve, İnönü, Selçuk and Karatay Universities in 2010-2011 academic year. The data were collected through SelfEfficacy Questionnaire (SEQ) and Autonomous Learner Questionnaire (ALQ) and analyzed by SPSS 19.0. The analysis of the data revealed that there was a positive relationship between self-efficacy and learner autonomy ( $r=.667 \mathrm{p}>.01)$, self-efficacy and academic success $(r=.597 \mathrm{p}>.01)$, and learner autonomy and academic success $(r=.506 \mathrm{p}>.01)$.
\end{abstract}

Index Terms—individual learning, learner autonomy, self-efficacy, academic Success

\section{INTRODUCTION}

Day by day, the importance of teaching and learning a language is increasing as the interaction among countries is soaring. As a result, since people try to learn more than one language to communicate with other people around the world, the rate of bilingual people is increasing. There are a lot of researches on the increasing rate of bilingual people. A research related to English-French bilingualism carried out in Canada is just an example of this. According to the research, about 5.231 .500 people reported to the 2001 census that they were bilingual, compared with 4.841 .300 five years earlier, an $8.1 \%$ increase. In 2001, these individuals represented $17.7 \%$ of the population, up from $17.0 \%$ in 1996 . According to the findings of the study, it can be said that the increasing rate of bilingual people can be observed around the world

Taking the importance of language teaching and learning in today's world into consideration, the study aims to reveal the missing point of the discussions related to foreign language teaching and learning in Turkey. While autonomy is a general human need, the support of which would enhance students' positive feelings about themselves and their school work (Zhou et al, M, 2009, p.493), self-efficacy is the beliefs in one's capabilities to organize and execute the course of action required to produce given attainments (Bandura, 1997b, p.3). It is clear that if one person has the ability to organize himself or herself and control himself or herself, it can be said that he/she is autonomous. Quinn (1974) claimed language teaching and learning is an autonomous art and it has accumulated over long periods. As he asserted, the process of language teaching and learning should be autonomous because language learning is a life-long journey. During this process, students should learn how to become autonomous and take the responsibility of their learning since there will not their teachers helping them during their life. As indicated in Chinese proverb "Give a man a fish and you feed for a day. Teach a man to fish and you feed him for a lifetime", teachers should teach students how to be autonomous and support autonomous learning in their classrooms due to the fact that language learning is also a lifelong process. Moreover, a person's autonomy allows new interpretations of the world and possibility of change (Kenny, 1993, p.440). It can be said that if students have high self-efficacy, they will be aware of their abilities and they will be more autonomous. In Turkey, there are different studies on self-efficacy and learner autonomy separately. However, there are almost no studies on the relationship between self-efficacy and learner autonomy. This study investigates the relationship between self-efficacy and learner autonomy, self-efficacy and academic success, and learner autonomy and academic success. The first major purpose of this study is to investigate not only whether there is a relationship between learner autonomy and self-efficacy but also to find out whether self-efficacy affects learner autonomy positively. Also, its aim is to find out learner autonomy affects students' learning in a positive way. While the questionnaire on self- 
efficacy reveals participants' self-efficacy scores, the questionnaire on learner autonomy reveals participants' learner autonomy scores in their language learning process. The scores bring the importance of the relationship between these two concepts into light in ELT. The second aim of this study is to reveal the relationships between self-efficacy and academic success, learner autonomy and academic success, and these two concepts (self-efficacy and learner autonomy) and academic success. Most teachers, learners, families and managers in schools complain that most learners cannot reach the proficiency level they desire in Turkey. The reason why they cannot attain the desired level of proficiency in foreign languages may be that people do not generally take the relationship between self-efficacy, learner autonomy and academic success in language learning into consideration. Moreover, as Yumuk (2002) indicates, the another reason may be that teachers' roles in Turkey do not allow students to be autonomous in classrooms. If students do not have the opportunity to explain themselves and control their own learning, they cannot be aware of their self-efficacy. This study helps to reveal the disregarded importance of the relationship between the two concepts (self-efficacy and learner autonomy) and academic success in language learning. In short, this study can have an effect on creating an effective language teaching and learning environment in Turkey. It may be a new road to the development of individual potential in language learning.

There is only a limitation encountered during this study. The results of the study cannot be generalized to all Turkish EFL learners because participants were selected from just only five universities in Turkey.

\section{LITERATURE REVIEW}

\section{A. Self-efficacy}

The societies of today have undergone different changes in the fields of information, society and technology. These dramatic changes are not new. However, what is new is their magnitude and accelerated pace (Bandura, 1997, p.1). This leads to continuous personal and social changes in the society. These challenging realities place a premium on people's sense of efficacy to shape their future (Bandura, 1997, p.1). Thus, what is self-efficacy? There are different definitions of the concept done by linguistics and educators as followed: "It is about learning how to persevere when one does not succeed (Pajares, 2005, p. 345).", "It is related to individuals' beliefs about the possibility of successfully performing a given academic task (Kornilova et al, 2009, p.597).", "It is the beliefs in one's capabilities to organize and execute the courses of action required to produce given attainments (Bandura, 1997b, p. 3).", "It is a process in which students' sense of ability to perform a task influences their success, which in turn contributes to increased effort and persistence (Aliegro, 2006, p.18). ". As it can be drawn from the definitions of the concept 'self-efficacy', the main logic behind all of the definitions is the same: individuals' beliefs have a very important place in their lifelong learning journey. Individuals' self-efficacy beliefs have a significant effect on how they think, feel, motivate themselves and take actions. These beliefs can increase or diminish their success in every field of their lives. In other words, individuals architect their own destinies by their sense of self-efficacy.

\section{B. Learner Autonomy}

Autonomy in the educational world has attracted educational authorities' attention as the result of the rise of ideologies of globalization, the information age and the knowledge-based economy (Benson, 2001). These changes have contributed to the rising of learner autonomy in the educational world and learner autonomy has gained its momentum within the context of language learning and teaching. As a result of the rising of learner autonomy, there has been a serious change in the degree of the control of learners' responsibilities and deciding how these responsibilities are performed for the recent years. It can be said that this may be a challenge to the role relationship between learners and teachers (Cotterall \& Crabbe, 1999, p.3). This relationship is likened to the relationship between a performer and a coach where the coach leads the performer to explore his/ her own world and reflect on it but not the relationship between a consumer and a provider in a traditional context. The questioning of these roles has been a fashion in today's education world and it has provided further food for thought in the aspect of a movement towards changing both teachers' and learners' roles in the classroom. This shift of responsibility from teachers to learners is generally referred to as 'learner autonomy' despite the fact that there are a number of different labels related to this concept (Cotterall \& Crabbe, 1999, p.3). In order to understand this concept well, educators and linguistics have tried to define the concept in different ways as followed: "It is the ability to take charge of one's own learning (Holec, 1981, p.3)", "It is the capacity to take control of one's own learning (Benson, 2001, p. 47).", "It is learners' ability and willingness to make choices independently (Little, 1996, p.97).", "It is the capacity for a certain range of highly explicit behavior that embraces both the process and the content of learning (Cotterall \& Crabbe, 1999, p.11).", and "It is a capacity and willingness to act independently and in cooperation with others as a social, responsible person (Dam et al., 1990, p.102).". As it can be drawn the definitions pointed out above, educators and linguists do not have a consensus on the term' learner autonomy'. However, the main gist of all the definitions is the same: learners build knowledge on their own and each learner brings his/her own experience and world knowledge to bear on the target language of task at hand (Candy, 1991, p. 270). It can be said that learner are the authors of their own education world. Although there have been a lot of different definitions about learner autonomy, it does not necessarily mean that the concept of learner autonomy has been fully understood (Oxford, 2003). 


\section{Academic Success}

Academic achievement is a developmental or cumulative process (Duncan et al, 2007). During this process, successful language learners could make themselves into legendary figures, influencing many others (Gao, 2010). However, as Bandura (1977) claimed, if they become a success, they have to keep it and that is the toughest thing about success.

There have been a lot of researches done on different variables such as age, cognition, native language, input, affective domain, motivation, learners' self efficacy, learner autonomy and educational background affecting academic success for a long time and it has attracted researchers', theorists' and practitioners' attention for the last years (Wilhelm, 1997 cited in Wenden, 1991).

It can be said that there are different factors such as self-efficacy, learner autonomy, age, motivation, gender, language aptitude, cognitive and learning styles, socio-cultural cultures, personality, and intelligence which have an effect on academic success.

\section{Self-efficacy and Academic Success}

Self-efficacy is valued not because of reverence for individualism but because a strong sense of self-efficacy is vital for successful adaptation and change (Bandura, 1997, p.32). Academic achievements can be predicted by individuals' sense of self-efficacy (Bandura, 1977). It can be said that successful learners have higher self-efficacy. Multon et al. (1991) makes a connection between self-efficacy beliefs and academic performance by saying that self-efficacy beliefs have a positive effect on learners' academic performance and persistence. The notion that academic self-efficacy beliefs influence academic success is obvious but it may be less apparent that non-academic factors such as child's effortful control could also directly or indirectly influence academic achievement (Liew et al, 2008, p. 516). According to their sense of self-efficacy, learners perform a task satisfactorily, unsuccessfully or extraordinarily. Learners' beliefs in their ability to perform a task or achieve their goals promote their success in learning a language process and it is almost the same in all the cultures.

There have been a lot of studies on self-efficacy but there is a limited number of studies about the relationship between self-efficacy and academic success. According to the result of these studies, self-efficacy beliefs play a very significant role in academic success (Dennissen,et al, 2007; Multon et al, 1991; Pajares, 1996).

Cotterall (1999) conducted a study on 113 students' language learning at Victoria University of Wellington during a 12-week period from November 1994 to February 1995. According to the findings of the study, majority of the participants believed that they had the ability to learn a language successfully and to find an effective way to learn. It can be said that learners' beliefs affect students' learning styles and this determines what kind of a learner they are. In addition to this, their sense of efficacy plays a key role in to what extent they are successful during learning a language.

In a similar vein, Liew, McTigue, Barrois and Hughes (2008) did a longitudinal study on self-efficacy and academic success. In the study, there were 733 first grade students examined during three years. According to the result of this study, self-efficacy beliefs were positively correlated with reading and math within and across time (Liew et al, 2008, p.515).

Ayotola and Adedeji (2009) also examined the relationship between mathematics self-efficacy and achievement. The result of the study showed the importance of self-efficacy beliefs in predicting students' performance in mathematics. It is clear from the study that there is a positive relationship between students' mathematics self-efficacy and achievement in mathematics.

In the line with previous studies, Bassi et al. (2007) conducted a research on 130 Italian students who were with high self-efficacy or with low self-efficacy. The participants of the study were observed for one week by an experience sampling method. During this period, students dealt with different academic tasks and were monitored in the aspect of their personal skills by the researchers. According to the result of this research, students with high self-efficacy are more motivated than students with low self-efficacy in educational contexts. Thus, high self-efficacious students pursuit more than students with low self-efficacy, spend more time on their learning process and become more successful.

In Turkey, there are a lot of studies on self-efficacy. However, there is a limited number of studies on the relationship between self-efficacy and academic success. Recent studies conducted on this issue are Duman's (2007), Cinkara's study (2009) and Yilmaz's study (2010). All of these studies support the idea that self-efficacy beliefs have a positive effect on students' success in learning English.

In brief, self-efficacy beliefs provide foundation for human motivation, well-being and personal accomplishment (Pajares, 2002). Individuals' sense of efficacy plays a critical role in their academic achievement and their life-long journey. Taking all these studies done on self-efficacy and academic success into consideration, researchers, educators and teachers should not ignore students' beliefs about their capability since their beliefs are vital components of motivation and academic success.

\section{Learner Autonomy and Academic Success}

There have been a lot researches done on learner autonomy over the past three decades (Benson, 2001; Cotterall, 1995; Littlewood, 1996). The researchers mentioned above support the idea that learner autonomy increases motivation to learn consequently; and so it increases learning effectiveness. This affects their academic success indirectly. If a learner does not accept his/her learning responsibilities, they will be unwilling to learn and so they will be unsuccessful 
during their learning life. As a result, there is a need for intervention in ongoing classroom practice to foster learner autonomy in order to provide an effective learning and teaching environment (Sanprasert, 2010).

Dam and Legenhausen (1996) conducted a project on learner autonomy in 1992. The aim of Language Acquisition in an Autonomous Learning Environment project was to observe the language development process of a Danish comprehensive school class in an autonomous language learning and teaching environment. According to the findings of the project, 7th grade learners in an autonomous class were better than learners following a more traditional language programme in the terms of C-test scores. This project supports the view that autonomous learning environment can affect learners' success in a positive way.

Nunan (1995) also conducted a project to investigate the effect of an autonomous learning environment on learners' learning process for over a twelve-week period. During this process learners took part in a language programmed designed with different modes such as co-operative learning, whole class work, pair and group work, learning beyond the classroom and individualized learning. At the end of this process, several changes were observed in students' learning behaviors. They became more communicative than before, preferred a more process-oriented approach to language learning rather than a product-oriented approach and began to take the control of their own learning. Also, they became more successful in their English courses than before. In short, it is clear from the study that autonomous learning environment affects students' learning in a positive way.

Taking its importance in the process of language learning into consideration, it can be said that educators and linguistics should not ignore its relation with academic success.

\section{Self-efficacy and Learner Autonomy in Relation to Academic Success}

Although learner autonomy and self-efficacy in language learning have been discussed separately for almost two decades, there is a general lack of data when it comes to investigating the relationship between self-efficacy and learner autonomy, and these two concepts (learner autonomy and self-efficacy) and academic success.

Overing did a study on the Piaroa that are jungle people dwelling along tributaries of the Orinoco in the Guiana Highlands of Venezula (Cotterall \& Crabbe, 1999, p. 34). They have a very highly developed theory of mind. According to them, there are two main forms of knowledge: ta'kwanya and ta'kwakomena. Ta'kwanya is related to the acquisition of cultural capabilities including the knowledge and capacity for using customs, language, social rules, rituals, and cuisine while ta'kwakomena is associated with the acquisition of one's own consciousness of and responsibility for such capacities. Personal autonomy is valuable. It is clear from Overing's study that at first, they are aware of their capabilities and capacity for using cultural values and then they take their responsibilities related to this issue in this community. It can be said that self-efficacy indirectly affects learner autonomy since without being aware of their cultural values they cannot realize their responsibilities and take them.

Concurrent to Overing's study, Lai conducted a study to raise learners' awareness of their own learning process and determining its effect on learners' capacity in their learning process during thirteen-week term period (Cotterall \& Crabbe, 1999). According to the result of this study, increasing self-efficacy indirectly affects students' autonomous skills. This study was very important in the aspect of searching new ways to empower learners with the capacity to organize their own learning (Cotterall \& Crabbe, 1999).

Briefly, it is very important to become aware of the knowledge and skills in the language learning process since we can manage our language learning process effectively. All the questions related to the language learning process such as "where am I?", "what are my goals?", "which strategies should I use to achieve my goals?" and "to what extent have I achieved my goals?" will be answered when a learner is aware of their capability and his/her responsibility in the learning process. It can be said that the more potential learners have for being autonomous, the more learning awareness they have (Cotterall, 2000). Development of learning awareness is a key objective of autonomous language learning (Dam \& Legenhausen, 1996). Awareness is a key concept in learner autonomy (Cotterall \& Crabbe, 1999, p.161).

\section{Methodology}

\section{A. Participants}

The data were collected from 50 preparatory level students out of 250 participants from each of the following universities: Gaziantep University, Zirve University, İnönü University, Selçuk University and Karatay University (144 male and 106 female students). According to information got from the instructors, their ages vary from 17 to 25 years. Participants were from faculty of engineering including, civil engineering, mechanical engineering, physic engineering, food engineering, textile engineering, electronic and electrical engineering, faculty of education and faculty of medicine.

\section{B. Instruments}

To collect data two different questionnaires were used. The questionnaires are scored according to a five-point Likert-type scale ranging from 1 (Never) to 5 (Always). The reliability of the questionnaires was analyzed by SPSS. The Cronbach Alpha coefficient of Self-Efficacy Questionnaire (SEQ) was .91 while the Cronbach Alpha coefficient of Autonomous Learner Questionnaire (ALQ) was .76. These values show that they are reliable instruments. The first questionnaire (SEQ) has 40 items focusing on questions related to students' self-efficacy. While 26 of these items were adapted from Bandura's Foreign Language Self-Efficacy Questionnaire, the rest of them were adapted from one of Ferla 
et al.'s (2009) study related to whether there is a theoretical or empirical difference between academic math self-concept and academic math self-efficacy. Also, the second questionnaire has 40 items related to learner autonomy that were adapted from different resources. While 30 of the items were adapted from Egel's questionnaire (2003), the rest of them were developed by examining different sources (Sancar, 2001; Koçak, 2003). In short, the questionnaires were developed by making use of different sources to investigate whether there is a relationship between self-efficacy and learner autonomy, self-efficacy and academic success, learner autonomy and academic success and these two concepts (self-efficacy and learner autonomy) and academic success.

\section{Data Collection}

The administrations of each university (Gaziantep, Zirve, İnönü University, Selçuk University and Karatay Universities) were given information about the study and the permissions were taken to conduct the study. The questionnaires were applied to 250 preparatory level students at the universities mentioned above in 2010-2011 education year. The researcher visited five universities and administered the questionnaires to the students during regular class hours in their classrooms. The participants were informed about the aim of the study. They were told that it was very important for data reliability of the questionnaire to answer the questions sincerely and the questionnaires did not include questions disturbing their personality. Then, the first of the questionnaires (SEQ) were handed out and the students filled out them at the beginning of the week. Each questionnaire had a number, and so the instructor was asked to match his/her students' names with the numbers in order to match SEQ with ALQ. The second questionnaire (ALQ) was applied to the students at the end of the week in order to avoid the negative effects of the first questionnaire on the second questionnaire through a similar process. Some of the students were not present in both questionnaires. Thus, they were excluded from the study.

\section{RESUlTS AND DISCUSSION}

This research was conducted by two questionnaires (SEQ and ALQ). The analysis of the results obtained through SEQ and ALQ unveil that there is a positive relationship between self-efficacy and academic success, learner autonomy and academic success, self-efficacy and learner autonomy, and two concepts and academic success. According to the analysis of the data, it can be said that self-efficacy affects academic success positively. Also, learner autonomy has a positive impact on academic success. Furthermore, self-efficacy and learner autonomy influence academic success in a positive way.

One of the aims of this study is to find out the relationship between self-efficacy and learner autonomy. The results of the Pearson Product Moment Correlation are shown in table 4.1.:

TABLE 4.1.

CORRELATION BETWEEN SELF-EFFICACY AND LEARNER AUTONOMY

\begin{tabular}{|l|l|l|l|}
\hline \multicolumn{4}{|c|}{ CORRELATION BETWEEN SELF-EFFICACY AND LEARNER AUTONOMY } \\
\hline \multirow{3}{*}{ Learner Autonomy } & Pearson Correlation & Learner Autonomy & Self-efficacy \\
\cline { 2 - 4 } & Sig. (2-tailed) & 1 & $.667 * *$ \\
\cline { 2 - 4 } & $\mathrm{N}$ & 250 & .000 \\
\hline \multirow{3}{*}{ Self-efficacy } & Pearson Correlation & $.667 * *$ & 250 \\
\cline { 2 - 4 } & Sig. (2-tailed) & .000 & 1 \\
\cline { 2 - 3 } & $\mathrm{N} * *$. Correlation is significant at the 0.01 level (2-tailed). & 250 \\
\hline
\end{tabular}

According to table 4.1., the Pearson Product Moment Correlation unveils a significant positive relationship between learner autonomy and self-efficacy among 250 preparatory level students from Gaziantep, Zirve, Selçuk, Karatay and İnönü Universities $(r=.667 \mathrm{p}>.01)$. It can be said that when participants' sense of self-efficacy increases, their potential to be autonomous learners also increases. There is almost no such a study to investigate the relationship between learner autonomy and self-efficacy in the field of language learning and teaching. However, some linguistics and educators have implied that there is a relationship between learner autonomy and self-efficacy in their studies (Benson, 2006; Cotterall 1995, 1999; Schmenk, 2005). Schmenk (2005) puts forth that the concept of autonomy has value; nevertheless, provided that language educators admit that autonomy is not a universal and neutral concept and that encompasses a critical awareness of one's own abilities, possibilities and limitations within particular concepts (Schmenk, 2005, p.115). As Schmenk (2005) claims, self-efficacy is a prerequisite for learner autonomy due to the fact that unless individuals become aware of their capabilities, they cannot manage their own learning and take responsibility of their own learning process. It can be said that the results of the studies mentioned above are parallel with the findings of this research confirming a strong link between learner autonomy and self-efficacy.

The second aim of the study was to show whether self-efficacy and learner autonomy affect academic success in a positive way or not. So as to reach this aim, the multiple regression was used. 
TABLE 4.2.

REGRESSION MODEL SUMMARY OF SELF-EFFICACY, LEARNER AUTONOMY AND ACADEMIC SUCCESS

\begin{tabular}{|l|l|l|l|l|}
\hline Model & R & R Square & Adjusted R Square & Std. Error of the Estimate \\
\hline 1 & $.614^{\mathrm{a}}$ & .377 & .372 & 9.70293 \\
\hline
\end{tabular}

a. Predictors: (Constant) Self-efficacy, Learner Autonomy

\begin{tabular}{|l|l|l|l|l|l|}
\hline Model & Sum of Squares & df & Mean Square & F & Sig. \\
\hline 1 Regression & 14072.581 & 2 & 7036.291 & 74.737 & $.000^{\mathrm{a}}$ \\
\hline Residual & 23254.255 & 247 & 94.147 & & \\
\hline Total & 37326.836 & 249 & & & \\
\end{tabular}

a. Predictors: (Constant), Self-efficacy, Learner Autonomy

b. Dependent Variable: Academic Success

\begin{tabular}{|l|l|l|l|l|l|}
\hline \multirow{2}{*}{ Model } & \multicolumn{2}{|l|}{ Unstandardized Coefficients } & Standardized Coefficients & \multirow{2}{*}{ t Sig. } \\
\cline { 2 - 4 } & $\mathrm{B}$ & Std. Error & Beta & & \\
\hline Constant & 27.136 & 4.478 & & 6.060 & .000 \\
\hline Learner Autonomy & .138 & .048 & .195 & 2.889 & .004 \\
\hline Self-efficacy & .241 & .035 & .467 & 6.930 & .000 \\
\hline
\end{tabular}

a. Dependent Variable: Academic Success

According to table 4.2., $\mathrm{R}$ value (.614 p >.01) shows the multiple correlation coefficient between two concepts (selfefficacy and learner autonomy) and academic success, and reveals that there is a positive significant relationship between learner autonomy, self-efficacy and academic success. The value of F (74.737) indicates that self-efficacy and learner autonomy significantly predict academic success among other variables such as age, language aptitude, intelligence, motivation, personality, socio-cultural factors, cognitive style, gender, native language, input, educational background and learning style that have an effect on academic success. According to this model, self-efficacy ( $\beta=.467$ $\mathrm{p}<.05)$ and learner autonomy $(\beta=.195 \mathrm{p}<.05)$ are significant predictors of academic success among other variables that affect academic success. Self-efficacy and learner autonomy account for $\% 37.7$ the variation in academic success among the other variables mentioned above. In short, self-efficacy and learner autonomy make a significant contribution to predicting academic success among other variables in language learning and teaching. This means that the more self-efficacious and autonomous learners are, the more successful they become in the process of learning a language.

The third aim of this study was to investigate the relationship between self-efficacy and academic success. For this, the Pearson Product Moment Correlation was applied.

TABLE 4.3.

CORRELATION BETWEEN SELF-EFFICACY AND ACADEMIC SUCCESS

\begin{tabular}{|c|c|c|c|}
\hline & & Self-efficacy & Academic Success \\
\hline \multirow[t]{3}{*}{ Self-efficacy } & Pearson Correlation & 1 & $.597 * *$ \\
\hline & Sig. (2-tailed) & & .000 \\
\hline & $\mathrm{N}$ & 250 & 250 \\
\hline \multirow{3}{*}{$\begin{array}{l}\text { Academic } \\
\text { Success }\end{array}$} & Pearson Correlation & $.597 * *$ & 1 \\
\hline & Sig. (2-tailed) & .000 & \\
\hline & $\mathrm{N}$ & 250 & 250 \\
\hline
\end{tabular}

As indicated in table 4.3., the obtained correlation $(\mathrm{r}=.597, \mathrm{p}>.01)$ shows that there is a significant relationship between self-efficacy and academic success. It can be said that learners with higher self-efficacy can accomplish more than the ones with lower self-efficacy. According to the findings of this study, students with higher self-efficacy at Gaziantep, Zirve, İnönü, Selçuk and Karatay Universities are more successful in the process of language learning that the ones with low self-efficacy. It shows that students' beliefs related to their capacity at these universities lead their performance success in the process of language learning. The studies on the relationship between self-efficacy and academic success confirm the results of this study (Magogwe \& Oliver, 2007; Ching, 2002; Ferla et al, 2008).

The fourth aim of the study was to explain the effects of self-efficacy on academic success. To achieve this, simple linear regression was conducted.

TABLE 4.4.

REGRESSION MODEL SUMMARY OF SELF-EFFICACY AND ACADEMIC SUCCESS

\begin{tabular}{|l|l|l|l|l|}
\multicolumn{5}{|c|}{ REGRESSION MODEL SUMMARY OF SELF-EFFICACY AND ACADEMIC SUCCESS } \\
\hline Model & R & R Square & Adjusted R Square & Std. Error of the Estimate \\
\hline 1 & $.597^{\mathrm{a}}$ & .356 & .353 & 9.84553 \\
\hline
\end{tabular}




\begin{tabular}{|l|l|l|l|l|l|}
\hline Model & Sum of Squares & df & Mean Square & F & Sig. \\
\hline 1 Regression & 13287.073 & 1 & 13287.073 & 137.073 & $.000^{\mathrm{a}}$ \\
\hline Residual & 24039.763 & 248 & 96.935 & & \\
\hline Total & 37326.836 & 249 & & & \\
\hline
\end{tabular}

a. Predictors: (Constant) Self-efficacy

b. Dependent Variable: Academic Success

\begin{tabular}{|l|l|l|l|l|l|}
\hline \multirow{2}{*}{ Model } & Unstandardized Coefficients & Standardized Coefficients & \multicolumn{2}{c|}{ t Sig. } \\
\cline { 2 - 4 } & B & Std. Error & Beta & \multicolumn{2}{c|}{} \\
\hline Constant & 36.112 & 3.272 & & 11.038 & .000 \\
\hline Self-efficacy & .308 & .026 & .597 & 11.708 & .000 \\
\hline
\end{tabular}

a. Dependent Variable: Academic Success

As shown in table 4.4. the regression analysis suggests a significant regression model in which self-efficacy explains \% 35 of variance in academic success among other variables such as age, gender, socio-economic factors, personality, learning style, language aptitude, intelligence, motivation, educational background, native language and input ( $\mathrm{R}$ Square $=.356 \mathrm{p}<.05)$. The value of $\mathrm{F}(137.073)$ indicates that self-efficacy predicts academic success. Selfefficacy $(\beta=.597 \mathrm{p}<.05)$ is a significant predictor of academic success among other variables. According to the result of simple linear regression analysis, It can be said that language learners with high self-efficacy at Gaziantep, Zirve, İnönü, Karatay and Selçuk Universities are more prone to becoming more successful learners than the ones with low self-efficacy. Students with high self-efficacy beliefs at these universities endured more than the ones with low selfefficacy when encountered with difficulties and obstacles and were more successful in academic achievement as supported by various researchers (Li \& Wang, 2010). In short, the present study confirms the fact that students' sense of efficacy beliefs is a key determinant of their academic success (Wong, 2005; Yang 2004 ).

The fifth aim of the study was to explore the relationship between learner autonomy and academic success.

TABLE 4.5.

CORRELATION BETWEEN LEARNER AUTONOMY AND ACADEMIC SUCCESS

\begin{tabular}{|l|l|l|l|}
\hline \multicolumn{2}{|c|}{} & Learner Autonomy & Academic Success \\
\hline \multirow{2}{*}{$\begin{array}{l}\text { Learner } \\
\text { Autonomy }\end{array}$} & Pearson Correlation & 1 & $.506^{* *}$ \\
\cline { 2 - 4 } & Sig. (2-tailed) & & .000 \\
\cline { 2 - 4 } & $\mathrm{N}$ & 250 & 250 \\
\hline \multirow{2}{*}{$\begin{array}{l}\text { Academic } \\
\text { Success }\end{array}$} & Pearson Correlation & $.506^{* *}$ & 1 \\
\cline { 2 - 4 } & Sig. (2-tailed) & .000 & 250 \\
\cline { 2 - 4 } & $\mathrm{N}$ & 250 & \\
\hline
\end{tabular}

**. Correlation is significant at the 0.01 level (2-tailed).

The table 4.5. presents that there is a significant positive relationship between learner autonomy and academic success $(\mathrm{r}=.506 \mathrm{p}>0.01)$. This means the more autonomous learners at Gaziantep, Zirve, İnönü, Selçuk and Karatay Universities are, the more successful they are. There have been numerous studies on the relationship between learner autonomy and academic success and they have a consensus on the view that learner autonomy and academic success are interrelated as confirmed in the present study (Zhou, Ma \& Deci, 2009; Cotterall, 1995; Mineishi, 2010).

The last aim of the study was to find out the effects of learner autonomy on academic success.

TABLE 4.6.

REGRESSION MODEL SUMMARY OF LEARNER AUTONOMY AND ACADEMIC SUCCESS

\begin{tabular}{|l|l|l|l|l|}
\hline Model & R & R Square & Adjusted R Square & Std. Error of the Estimate \\
\hline 1 & .506 & .256 & .253 & 10.58304 \\
\hline \multicolumn{4}{|c|}{ a. Predictors: (Constant) Learner Autonomy }
\end{tabular}

\begin{tabular}{|l|l|l|l|l|l|}
\hline Model & Sum of Squares & df & Mean Square & F & Sig. \\
\hline 1 Regression & 9550.661 & 1 & 9550.661 & 85.273 & $.000^{\mathrm{a}}$ \\
\hline Residual & 27776.175 & 248 & 112.001 & & \\
\hline Total & 37326.836 & 249 & & \\
\hline
\end{tabular}

\begin{tabular}{|l|l|l|l|l|l|}
\hline \multirow{2}{*}{ Model } & Unstandardized Coefficients & Standardized Coefficients & \multirow{2}{*}{ t } \\
\cline { 2 - 5 } & B & Std. Error & Beta & \\
\hline Constant & 29.134 & 4.874 & & 5.977 & .000 \\
\hline Learner Autonomy & .358 & .039 & .506 & 9.234 & .000 \\
\hline
\end{tabular}

As indicated in table 4.6., R-value (.506 p >.01) shows the correlation coefficient between learner autonomy and academic success, and reveals that there is a positive significant relationship between learner autonomy and academic success. This means that the more autonomous learners are, the more successful they become. As it is clear in table 4.6., 
the regression analysis suggests a significant regression model in which learner autonomy explains \% 25,6 of variance in academic success among other variables such as age, gender, motivation, cognitive style, learning style, language aptitude, socio-economic factors, educational background, native language, and input ( $\mathrm{R}$ Square $=.256 \mathrm{p}<.05$ ). The value of $F(85.273)$ indicates that learner autonomy predicts academic success. Learner autonomy $(\beta=.506 \mathrm{p}<.05)$ is a significant predictor of academic success among the other variables. According to the findings of the present study, students who are more autonomous at Gaziantep, Zirve, İnönü, Karatay and Selçuk Universities have been observed that they have become more successful in the process of language learning. It is clear that students participating in a classroom at these universities where they are given more opportunities to become autonomous are more likely to perform better in learning a language. The findings of this study confirm that learner autonomy plays a significant role in academic success in the field of language learning (Dafei, 2007; Yen \& Lui, 2009).

\section{CONCLUSION AND RECOMMENDATIONS}

The most important finding of the present study is the relationship between learners' beliefs related to their language potential and their responsibility for their roles as language learners. The findings of the present study have unveiled the fact that there is a significant positive relationship between self-efficacy and learner autonomy $(r=.667, p>.01)$ and also have revealed that self-efficacy and learner autonomy affect academic success in a positive way according to the result of multiple regression analysis. There are a lot of researches on the relationship between self-efficacy and language learning, and learner autonomy and other student-focused constructs such as self-motivation, self-regulation, agency and identity (Benson, 2006). When comparing the present study with existing literature, it can be said that in most of these researches, learner autonomy and self-efficacy have been studied separately or compared or contrasted with other variables such as age, language aptitude, academic success, educational background, gender and motivation. To illustrate this, many researchers have conducted studies on the relationship between self-efficacy and academic success (Yılmaz, 2010; Cinkara, 2009; Duman, 2007; Liew, McTigue, Barrois \& Hughes, 2008; Ayatola \& Adedeji, 2009) while some researchers have studied on learner autonomy and academic success (Dam \& Legenhausen, 1996; Nunan, 1995; Yen \& Liu, 2009). Nonetheless, they have not integrated self-efficacy with learner autonomy and investigated their effect on learners' language performance in their studies. Thus, it is clear that there is no such a study on the relationship between self-efficacy and learner autonomy, these two concepts (self-efficacy and learner autonomy) and academic success in the field of ELT. This study is the first one in the field. The main point of departure for the present study has been the missing pieces related to ELT in Turkey. In Turkey, most of language learners complain that they cannot achieve their full potential although they have been exposed to English for at least 9 years until they become university students. The problem behind this may be that both the relationship between self-efficacy and learner autonomy and these two concepts and academic success may be ignored. The present study establishes students' sense of efficacy to guide their autonomous learning as a key factor affecting their performance outcomes related to language learning. Despite the fact that these two concepts have been studied separately, they cannot be considered separately in ELT. As indicated in "Maintaining Control: Autonomy and Language Learning", no real progress towards autonomy can be made without attending to learner beliefs because of the important influence they have on learner reflection and metacognition (Pemberton et al, 2009, p.54). The findings of the present study are consistent with some points reported in earlier studies. Carter (1999) implies the importance of learners' beliefs in the process of being autonomous learners during language learning process according to the findings of his study. Wenden (1991) also declared that autonomous learners are self-confident learners believing in their ability to learn and to self-direct or manage their learning (Wenden, 1991, p.53). The results of the present study extend previous findings on the relationship between self-efficacy and learner autonomy and the effect of the integration of these two concepts on academic success in the process of language learning and teaching. The previous studies did not show the effect of these two concepts on academic success together in ELT. According to the result of the present study, students with high self-efficacy at Gaziantep, Zirve, İnönü, Selçuk and Karatay Universities are more prone to becoming autonomous in the process of language learning because learners' beliefs related to their capacity in their language learning process affect to what extent they are autonomous. It is clear that learners at these universities are aware of their capacity in English and they believe in themselves. These students with high self-efficacy can control their own learning since they know that they have the capacity. In addition to this, both self-efficacious and autonomous learners at these universities mentioned above have been observed that they have become more successful in the process of language learning. It can be said that self-efficacy and learner autonomy are two most important predictors of academic success in the field of language learning.

The present study has revealed that self-efficacy, learner autonomy and the relationship between these two concepts (self-efficacy and learner autonomy) and academic success have an important place in language learning and teaching. In short, the present study revealed the disregarded importance of the relationship between two concepts (self-efficacy and learner autonomy) and language learning in the field of ELT. It implies that the relationship between self-efficacy and learner autonomy should be emphasized simultaneously in the process of language teaching and learning. This integration will contribute to successful outcomes related to language learning and the present study will be a step in the new direction of language teaching and learning in Turkey. It can be said that learner autonomy and self-efficacy go hand in hand in the process of language learning, and this study may be a new road to the development of individual potential in language learning. 


\section{RECOMMENDATIONS FOR FURTHER RESEARCH}

The promotion of an effective learning and teaching environment depends on the education system. Turkish education system can be defined as a traditional, teacher-dominated, and authority-oriented system since it is still directed and evaluated by the instructors. Most instructors are not autonomous in Turkey. As Little (2005) claims that teachers who themselves are not autonomous may have negative influence on the development of self-efficacious and autonomous learners. Therefore, in Turkey, there is no significant step to promote these in educational settings.

According to different studies on learner autonomy in Turkey, the only activity to promote learner autonomy is 'group work' in the lesson plans and the curriculum. As Harmer (2001) claims, group work promotes learner autonomy. However, there should be more activities that make students be aware of their own capacity and control their own learning in the curriculum.

Turkish learners need to develop a critical awareness of language learning. One possible solution for this situation can be to make students become aware of their capacity and promote their autonomy through curriculum (Cotterall, 2000). As teachers and administrators, the principles of autonomy and self-efficacy should be integrated into:

- The learning goal

- The learning process

- Tasks

- Learner strategies

- Reflection on learning (Cotterall, 2000)

The study reveals that self-efficacy, learner autonomy and the relationship between these two concepts (self-efficacy and learner autonomy) and academic success have an important place in language learning and teaching. However, in Turkey, there is no such study to investigate the importance of the relationship between self-efficacy and learner autonomy, and these two concepts (self-efficacy and learner autonomy) and academic success. This study is the first one in the field. First, in future researches, the relationship between self-efficacy and learner autonomy, and these two concepts (self-efficacy and learner autonomy) and academic success might be studied in detail. Moreover, researchers and educators should pay more attention to the importance of the relationship between self-efficacy and learner autonomy, and these two concepts and academic success in language learning and teaching in the process of developing the curriculum because the results of the present study indicate that the integration of self-efficacy and learner autonomy in the process of language teaching and learning exerts some influences on the effectiveness of practicing what students have learnt related to foreign languages. Thus, it is recommended that EFL teachers should be aware of the importance of these two concepts (self-efficacy and learner autonomy) during the process of language teaching and learning. Secondly, the present study was conducted by using quantitative methods. Further research may include both quantitative and qualitative methods such as classroom observations and interviews due to the fact that this might help the researchers to understand students' sense of self and their attitudes towards being autonomous learners better while learning a language. Thirdly, there were 250 participants from five universities (Gaziantep, Zirve, İnönü, Selçuk and Karatay Universities) in the study. Because of this, the generalizability of findings may be limited. Therefore, further research may consist of a wider range of samples from more universities in Turkey. Lastly, further research may be conducted on the relationship between these two concepts (learner autonomy and self-efficacy) and other variables such as age, language aptitude, intelligence, personality, socio-cultural factors, cognitive style, age, motivation, educational background and learning style that affect learners' academic success in the process of language learning in Turkish EFL context in detail.

\section{REFERENCES}

[1] Aliegro, J. C. (2006). The effect of self-assessment on the self-efficacy of students studying Spanish as a foreign language. Ph. D. Dissertation, University of Pittsburg Graduate Faculty of School of Education, Pennysylvania.

[2] Ayotola, A. and Adedeji, T. (2009). The relationship between mathematics self-efficacy and achievement in mathematics. Procedia Social and Behavioral Sciences, 1:953-957.

[3] Bandura, A. (1977). Self-efficacy: Toward a unifying theory of behavioral change. Psychological Review, 84, $191-215$.

[4] Bandura, A. (1997). Self-efficacy: The Exercise of Control. New York: Freeman.

[5] Bandura, A. (1997b). Exercise of personal and collective efficacy in changing societies. In: Bandura, A, Self-efficacy in Changing Societies, Cambridge University Press, London.

[6] Bassi, M., Steca, P., Della Fave, A., and Caprara, G. V. (2007). Academic self-efficacy beliefs and quality of experience in learning. Journal of Youth and Adolescence, 301-312.

[7] Benson, P. (2001). Teaching and Researching Autonomy in Language Learning. Longman, London.

[8] Benson, P. (2006). Autonomy in language teaching and learning. State-of-the-art Article, 40:21-40.

[9] Candy, P.C. (1991). Self-direction for Lifelong Learning. San Francisco: Jossey-Bass.

[10] Carter, B.A. (1999). Begin with beliefs: Exploring the relationship between beliefs and learner autonomy among advanced students. Texas Papers in Foreign Language Education, 4(1): 1-20.

[11] Ching, L.C. (2002). Strategy and self-regulation instruction as contributors to improving students' cognitive model in an ESL programme. English for Specific Purposes, 13:261-289.

[12] Cinkara, E. (2009). Self-efficacy in EFL: Its sources and relationship with success (A case study at Gaziantep University). Master's Thesis, Gaziantep University Graduate School of Social Sciences, Gaziantep. 
[13] Cotterall, S. (1995). Readiness for autonomy: Investigating learner beliefs. System, 23(2):195-205.

[14] Cotteral, S. (1999). Key variables in language learning: What do learners believe about them? System, 2(4):493-513.

[15] Cotterall, S. M. (2000). Promoting learner autonomy through the curriculum: principles for designing language courses. ELT Journal, 54(2):109-117.

[16] Cotterall, S. and Crabbe, D. (1999). Learner Autonomy in Language Learning: Defining the Field and Effecting Change. Peter Lang.

[17] Dafei, D. (2007). An exploration of the relationship between learner autonomy and English proficiency. Asian EFL Journal, 123.

[18] Dam, L., Eriksson, R. , Little, D., Milliander, J. and Trebbi, T. (1990). "Towards a definition of autonomy" in T. Trebbi (ed.) Third Nordic Workshop on Developing Autonomous Learning in FL Classroom. Bergen: University of Bergen. http:// www.warick.ac.uk/go/dahla/archive/trebbi_1990.

[19] Dam, L. and Legenhausen, L. (1996). The acquisition of vocabulary in an autonomous learning environment -the first months of beginning English. In Pemberton, R. et al. (eds). Taking Control: Autonomy in Language Learning: 265-280. Hong Kong: Hong Kong University Press.

[20] Dennissen, J. J. A., Zarrett, N. R. and Eccles, J. S. (2007). I like to do it, I'm able, and I know I'm: Longitudinal couplings between domain specific achievement, self-concept, and interest. Child Development, 78:430-447.

[21] Duman, B. (2007). The effects of self-efficacy beliefs of high school students about English on their English performance due to gender, range and grade. PhD. Dissertation, Yıldız Technical University Graduate School of Social Sciences, İstanbul.

[22] Duncan G. J., Dowsett, C.J., Claessens, A., Magnuson, K., Huston, A.C., and Klebanow, P. (2007). School readiness and later achievement. Developmental Psychology, 43:1428-1446.

[23] Egel, İ. P. (2003), The Impact of the European Language Portfolio on the Learner Autonomy of Turkish Primary School Students, Unpublished doctoral dissertation, Anadolu University, Eskişehir.

[24] Ferla, J., Valcke, M. and Cai, Y. (2009). Academic self-efficacy and academic self-concept: Reconsidering structural relationships. Learning and Individual Difference, 19: 499-505.

[25] Ferla, J., Valcke, M., and Schuyten, G. (2008). Relationships between student cognitions and their effects on study strategies. Learning and Individual Differences, 18(2):271-278.

[26] Gao, X. (2010). Autonomous language learning against all odds. System:1-11.

[27] Holec, H. (1981). Autonomy in Foreign Language Learning. Oxford: Pergamon.

[28] Kenny, B. (1993). For more autonomy. System, 21(4):431-442.

[29] Koçak, A. (2003). A study on learners' readiness for autonomous learning of English as a foreign language. Yayımlanmamış Yüksek Lisans Tezi. Orta Doğu Teknik Üniversitesi, Ankara.

[30] Kornilova, T. V., Kornilov, S.A., and Chumakova, M. A. (2009). Subjective evaluations of intelligence and academic selfconcept predict academic achievement: Evidence from a selective student population. Learning and Individual Differences, 19:596-608.

[31] Li, Y. and Wang, C. (2010). An empirical study of reading self-efficacy and the use of reading strategies in Chinese EFL context. Asian EFL Journal, 12(2):144-162.

[32] Liew, J., McTigue, E., M., Barrois, L and Hughes, J., N. (2008). Adaptive and effortful control and academic self-efficacy beliefs on achievement: A longitudinal study of 1st through 3rd graders. Early Childhood Research Quarterly, 23:515-526.

[33] Little, D. (1996). The politics of learner autonomy. Learning Learning, 2(4):7-10.

[34] Littlewood, W. (1996). Autonomy: an anatomy and a framework. System, 24(4): 427-435.

[35] Magogwe, J. M. and Oliver, R. (2007). The relationship between language learning strategies, proficiency, age and selfefficacy beliefs: A study of language learner in Botswana. System, 35: 338-352.

[36] Mineishi, M. (2010). East Asian EFL learners' autonomous learning, learner perception on autonomy and portfolio development: In the case of educational contexts in Japan. International Journal of Art and Sciences, 3(17): 234-241.

[37] Multon, K. D., Brown, S. D. and Lent, R. W. (1991). Relation of self-efficacy beliefs to academic outcomes: A meta-analytic investigation. Journal of Counseling Psychology, 38: 30-38.

[38] Nunan, D. (1995). Closing the gap between learner and instruction. TESOL Quarterly, 29 (1):133-158.

[39] Oxford, R.L. (2003). Toward a more systematic model of L2 learner autonomy. In D. Palfreyman \& R.C. Smith (Eds.) Learner Autonomy across Cultures: Language Education Perspectives. Basingstoke: Palgrave Macmillan.

[40] Pajares, F. (1996). Self-efficacy beliefs in academic settings. Review of Educational Research, 66(4), 543-578.

[41] Pajares, F. (2002). Overview of social cognitive theory and of self-efficacy. Retrieved January 11, 2004, from http://www.emory.edu/EDUCATION /mfp/eff.html.

[42] Pajares, F. (2005). Self-efficacy during childhood and adolescence: Implications for teachers and parents. In F. Pajares \& T. Urdan (Eds.), Self-efficacy and Adolescence pp.339-367. Greenwich, CT: Information Age.

[43] Pemberton, P., Toogood, S. and Barfield, A. (2009). Maintaining Control: Autonomy and Language Learning. Barfield: Hong Kong University Press.

[44] Sancar, I. (2001). Learner Autonomy: A Profile of Teacher Trainees in Pre-service Teacher Education. Unpublished Master's of Art Thesis. Uludağ Üniveritesi, Bursa.

[45] Sanprasert, N. (2010). The application of a course management system to enhance learner autonomy in learning English as a foreign language. System, 38: 109-123.

[46] Schmenk, B. (2005). Globalizing learner autonomy. TESOL Quarterly, 31(1):107-118.

[47] Quinn, J.T. (1974). Theoretical foundations in linguistics and related fields. Responding to New Realities. ACTFL Review of Foreign Language Education 5, 25.

[48] Wenden, A. (1991). Learner Strategies for Learner Autonomy: Planning and Implementing Learner Training for Language Learners. UK: Prentice Hall.

[49] Wong, M.S. (2005). Language learning strategies and language self-efficacy. Regional Centre Journal, 36(3):245-269. 
[50] Yang, L.L., (2004). The development of a validated perceived self-efficacy scale on English reading strategies. Journal of Education \& Psychology 27(2), 377-398.

[51] Yen, C. J. and Liu, S. (2009). Learner autonomy as a predictor of course success and final grades in community college online courses. Journal of Educational Computing Research, 41(3):347-367.

[52] Yilmaz, C. (2010). The relationship between language learning strategies, gender, proficiency and self-efficacy beliefs: a study of ELT learners in Turkey. Procedia Social and Behavioral Sciences, 2:682-687.

[53] Zhou, M., Ma, W.J. and Deci, E. L. (2009). The importance of autonomy for rural Chinese children's motivation for learning. Learning and Individual Difference, 19: 492-498.

Filiz Yalcin Tilfarlioglu has received her B.A. from the University of İstanbul, E.L.T. Department. She has written articles on different research topics related to the field and accomplished her PHD at the University of Çukurova.

Fatma Seyma Ciftci was born in Şanlıurfa in Turkey in 1988. She graduated from the Foreign Language Education Department English Language Teaching Program at Middle East Technical University in 2009. She has received her M.A from the University of Gaziantep in 2011. She has been working as an English language instructor at Adiyaman University since 2009. 